Tohoku J. exp. Med., 1977, 122, 155-160

\title{
Growth Behavior of Ascites Tumor Cells in Three-Dimensional Agar Culture
}

\author{
Haruo Sato, Masayoshi Goto and Shigetoshi Hosaka \\ Department of Oncology, Research Institute for Tubercurosis \\ Leprosy and Cancer, Tohoku Lniversity, Sendai
}

Sato, H., Goto, M. and Hosaka, S. Grouth Behavior of Ascites Tumor Cells in Three-Dimensional Agar Culture. Tohoku J. exp. Med., 1977, 122 (2), 155-160 __ Growth behavior in vitro of ascites tumor cells was examined for a model study on the invasion in cancer. For this purpose three-dimensional agar culture was used. Seventeen strains of tumor cells were used. These tumor cells grow floating in ascites as single isolated cells (single cell strain) or forming different per cent of cell aggregates (island type strain). Plating efficiencies of tumor cells were variable, depending on the kinds of tumor strain. It was noted that FM3A cells of the cultured cell line showed almost $100 \%$ plating efficiency irrespective of the number of cells inoculated. Tumor cells formed 3 types of colony; that is, solid type, mushroom-shaped and disk-shaped colony. These three types of colony were observed in all the tumor strains tested, depending on the position in agar layer. The cells of single cell strains showed the tendency to form loose colonies in which cell contact was loose and cells were easy to liberate from the periphery of the colony. The cells of island type strains showed the tendency to form packed colonies in which cell contact was tight. Growth behavior of cells of ascites tumor in agar medium showed good correlation with that in susceptible animals. - growth; matastasis

Rat ascites tumors were established in Japan by ascitic conversion of the liver cancer produced by feeding with azo-dye (Odashima 1964). Many ascites tumor strains have been maintained by serial transplantation through peritoneal cavity and each of them has its own biological characteristics. Some ascites tumor cells such as Yoshida sarcoma cells have high ability to form metastasis. When ascites tumor cells were transplanted subcutaneously, the cells of tumor strains consisting of single isolated cells showed remarkable invasive growth into the surrounding tissue, while the cells of tumor strains consisting partly of cell aggregates in ascites figure had a tendency of less invasive growth.

Many factors may be involved in the invasion of tumor cells into surrounding tissue, including degree of liberation of cells from tumor nodule and mobility of cells. Obviously invasive growth can be studied in this entity in the living system. However, in vitro system provides advantage due to elimination of variable and

Received for publication, December 23, 1976.

This work was supported in part by a Grant-in-Aid for Scientific Research from the Ministry of Education, Science and Culture, Japan.

Present address of M.G. is Department of Pharmacology, Pharmaceutical Institute,

Tohoku University, Sendai. 
complex factors. In this paper growth behavior of ascites tumor cells in agar culture of three-dimensional system was studied to examine quantitatively invasive growth of tumors.

\section{Materials and Methods}

\section{Ascites tumor strains}

Ascites tumor strains used in this study were Yoshida sarcona, GV, AH-13, AH-13C, $\mathrm{AH}-13 \mathrm{M}$, AH-13R, AH-66F, AH-797F, $\mathrm{AH}-130 \mathrm{~F}(\mathrm{G})$ and $\mathrm{AH}-130 \mathrm{~F}(\mathrm{SI})$. They grow floating in ascites as single isolated cells when transplanted into peritoneal cavity of Donryu rats. Other kinds of tumor strain used were $\mathrm{AH}-7974, \mathrm{AH}-130, \mathrm{AH}-423, \mathrm{AH}-62 \mathrm{~F}$, $\mathrm{AH}-13 \mathrm{IB}$ and $\mathrm{AH}-39$ (Odashima 1964). AH-13C, AH-13M and AH-13R were sublines of $\mathrm{AH}-13$ resistant to mitomycin $\mathrm{C}, 6$-mercaptopurine and nitrogen mustard, $\mathrm{GV}$ was a tetraploid subline of Yoshida sarcoma. $\mathrm{AH}-130 \mathrm{~F}(\mathrm{G})$ and $\mathrm{AH}-130 \mathrm{~F}\left(\mathrm{~S}_{1}\right)$ were sublines of single isolated cells in ascitic figure derived from AH-130. Cultured cell lines were FN3A (Yamane and Nakano 1966), MH-134, L cells and HeLa cells.

\section{Three-dimensional agar culture}

Agar culture was a modified method by Macpherson and Montagnier (1964). Basal medium was Eagle's MEM containing $20 \%$ bovine serum, $1.0 \times 10^{-4} \mathrm{M}$ serine, $1.0 \times$ $10^{-4} \mathrm{M}$ sodium pyruvate, penicillin $(100 \mathrm{U} / \mathrm{ml})$ and Kanamycin $(100 \mu \mathrm{g} / \mathrm{ml})$. Agar cultures consisted of two layers, base layer and upper layer where colls were suspended. Concentration of agar was $1.0 \%$ in base layer and $0.5 \%$ in upper layer. Noble agar (Difeo Lab., Detroit, U.S.A.) was dissolved in Bacto-peptone (Difco Lab., Detroit, U.S.A.) solution (Bacto-peptone $20 \mathrm{~g}$, glucose $1 \mathrm{~g}$, NaCl $5 \mathrm{~g}, \mathrm{Na}_{2} \mathrm{HPO}_{4} \cdot 12 \mathrm{H}_{2} \mathrm{O} 2.5 \mathrm{~g}$, redistilled water $1000 \mathrm{ml}$ ) to give $5 \%$ concentration, followed by dilution with basal culture medium to make $1.0 \%$ agar medium which was poured to culture dishes as base layer. Remains of $1.0 \%$ agar medium was diluted to make $0.5 \%$ agar medium with basal culture medium preincubated at $37^{\circ} \mathrm{C} . \quad 0.5 \%$ agar medium containing cells was poured on the top of the base layer (Goto and Sato 1965). Culture dishes were incubated in an incubator with $95 \%$ air $5 \% \mathrm{CO}_{2}$ at $37^{\circ} \mathrm{C}$.

\section{Results}

\section{Plating efficiency}

When single isolated cells of ascites tumors were suspended in the agar medium, almost all of the cells were visible as single free cells under microscope. Around 7 days after cultivation colonies became visible and continued growing for futher cultivation. Plating efficiencies of tumor cells are shown in Fig. 1. Among ascites tumor strains plating efficiencies of $\mathrm{AH}-7974$ and $\mathrm{AH}-13 \mathrm{M}$ were high, whereas $\mathrm{AH}-130 \mathrm{~F}\left(\mathrm{~S}_{1}\right)$, AH-131B, AH-39 showed very low plating efficiency. A point of interest was the plating efficiency of FM3A cells which showed almost $100 \%$ plating efficiency irrespective of the inoculum size of cells. Plating efficiencies of cells of many tumor strains were affected by the number of cells inoculated (Fig. 1).

\section{Growth behavior}

There were 3 types of colonies observed in agar culture; that is, solid type (Fig. 2), mushroom-shaped (Fig. 3) and disk-shaped (Fig. 4). It seems to be 


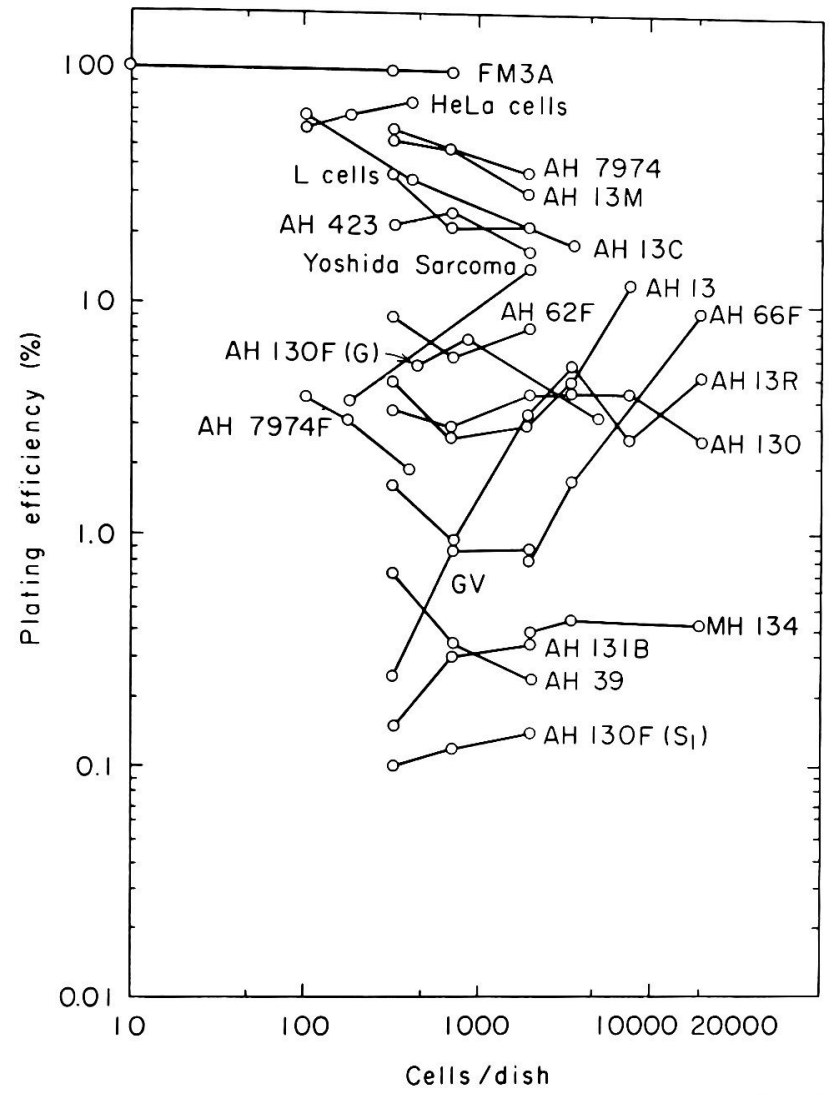

Fig. 1. Plating efficiencies of cells of ascites hepatomas of rats and culture cell lines. Each value is mean of 8-10 dishes.
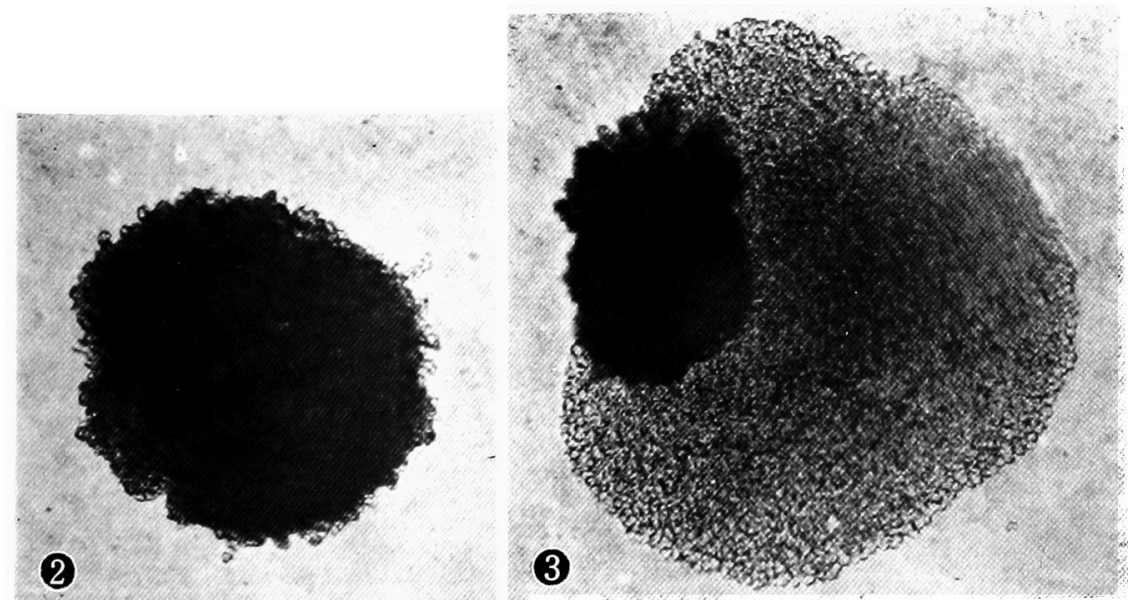

Fig. 2. Solid type of colony of AH-62F cells in agar medium after cultivation for 16 days. Unstained. $\times \mathbf{4 0}$

Fig. 3. Mushroom-shaped colony of $\mathrm{AH}-62 \mathrm{~F}$ cells in agar medium after cultivation for 16 days. Unstained. $\times 40$ 


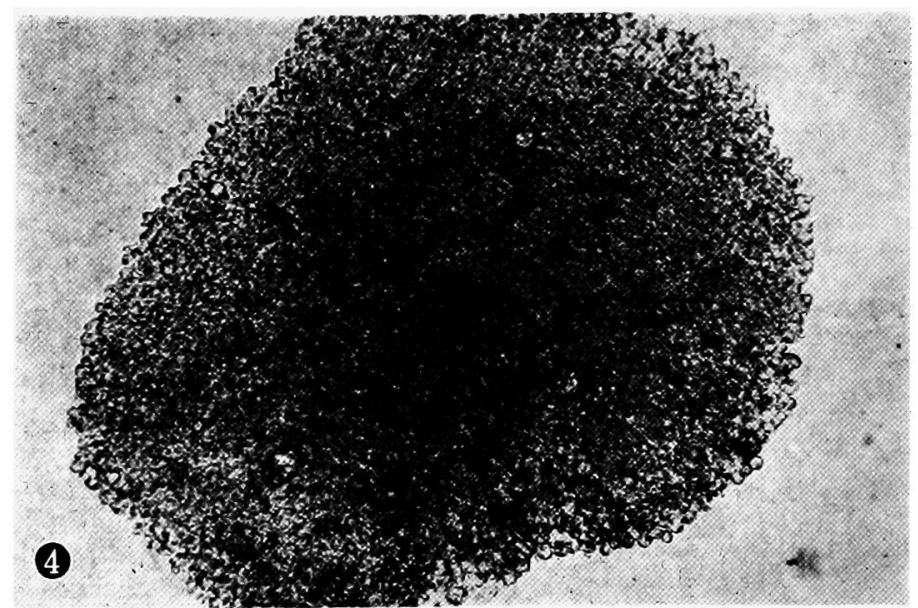

Fig. 4. Disk-shaped colony of $\mathrm{AH}-62 \mathrm{~F}$ cells in agar medium after cultivation for 16 days. Unstained. $\times 40$

dependent on the position of cells in upper layer that the cells form one of three types of colony. The cells resting near the surface of upper layer may form mushroomshaped colony after forming first core part of colony and then halo part of colony (Fig. 3). The cells positioned in the middle of layer seem to form solid type colonies. The cells positioned between the upper and base layer seem to form diskshaped colonies. In fact mushroom-shaped colonies began to appear after the appearance of other two colony types. These three colony types were observed in all the tumor strains tested.

The remarkable finding was that some tumor cells formed packed colony like stone, where the boundary between colony and agar matrix was clear (Fig. 5).

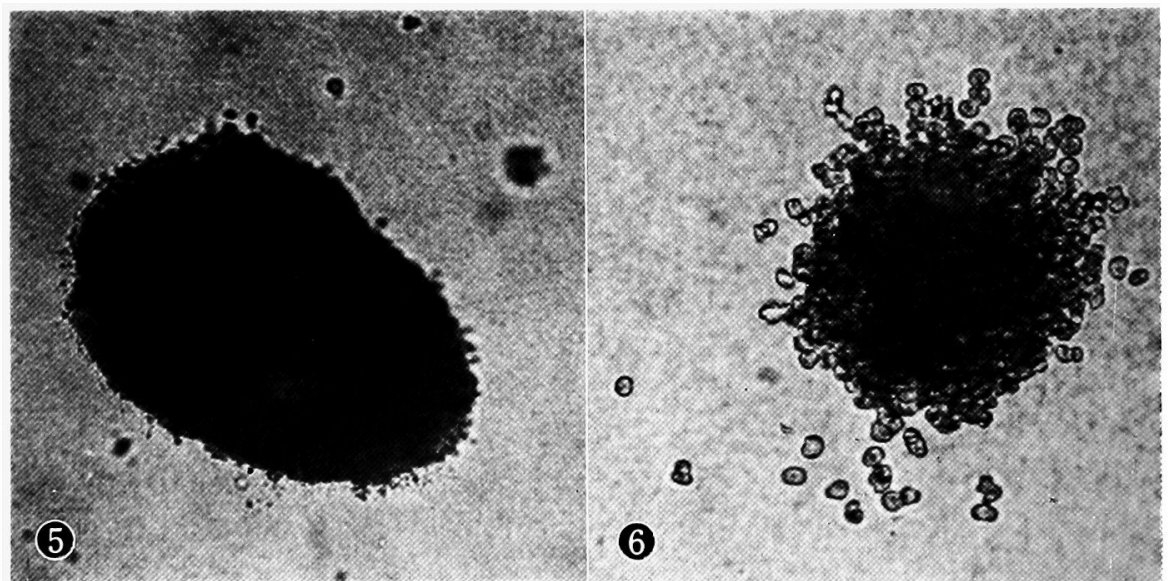

Fig. 5. Packed colony of AH-130 cells in agar medium after cultivation for 7 days. Note tight contact of cells in colony. Unstained. $\times 40$

Fig. 6. Loose colony of AH-13 cells in agar medium after cultivation for 14 days. Note liberation of cells at periphery of colony. Unstained. $\times 100$ 
Other tumor cells such as Yoshida sarcoma cells formed loose colonies looking like cloud where the contact of cells was loose and cells were separated (Fig. 6). In the loose colonies the cells showed remarkable invasive growth into surrounding agar matrix. In the packed colonies cell contact was tight and the cells showed the expanding growth into the surrounding agar matrix.

Tumor strains composed of single isolated cells in ascitic figure had the tendency to form loose colony, while those composed of single cells and cell aggregates showed the tendency to form packed colony. Cultured cells such as FM3A, L cells and HeLa cells formed packed colonies when observed under microscope.

\section{Discussion}

When ascites tumor cells are transplanted subcutaneously, the cells of the strains composed of single cells in ascitic figure such as $\mathrm{AH}-13, \mathrm{AH}-7974 \mathrm{~F}$ and $\mathrm{AH}-66 \mathrm{~F}$ show remarkable invasive growth into the surrounding tissue, whereas the cells of the strains composed in part of cell aggregates such as AH-7974 and AH-130 have a tendency of less invasive growth. The property of invasive growth plays an important role in metastasis formation of cancer.

A large number of culture system were devised to analyze the invasive growth of tumor cells. Abercrombie et al. (1957) used two-dimensional monolayer culture system for evaluation of invasive or infiltration of tumor cells. Leighton et al. (1959) devised three-dimensional sponge matrix culture in which normal cells were grown first and then confronted with tumor cells. Easty and Easty (1963) used organ culture. Schleich (1973) developed rotation-induced aggregation method.

In this study we used three-dimensional agar matrix as substrate into which tumor cells migrated or infiltrated. The cells of single isolated strains migrated easily into the surrounding agar matrix, resulting in the formation of loose colony. However, the cells of strains composed in part of cell aggregates in ascitic figure showed rather expanding growth into agar matrix. It is likely that mobility of cells is remarkable in the strains composed of single isolated cells and contact of cells is predominant in the strains composed of cell aggregates. It was confirmed in this study that growth of tumor cells in agar culture correlated well with the growth behavior in vivo. Three-dimensional agar culture system seems useful to analyze growth behavior of tumor cells.

\section{References}

1) Abercrombie, M., Heaysman, J.E.M. \& Karthauser, H.M. (1957) Social behaviour of cells in tissue culture III. Mutual influence of sarcoma cells and fibroblasts. Exp. Cell Res., 13, 267-291.

2) Easty, G.C. \& Easty, D.M. (1963) An organ culture system for the examination of tumor invasion. Nature (Lond.), 199, 1104-1105.

3) Goto, M. \& Sato, H. (1965) Studies on tissue culture of ascites tumors III. Colony formation of Yoshida sarcoma cells in agar medium. Sci. Rep. Res. Inst. Tohoku Univ. - $C, 12,319-323$. 
4) Leighton, J., Kalla, R.L., Kline, I. \& Belkin, M. (1959) Pathogenesis of tumor invasion I. Interaction between normal tissues and transformed cells in tissue culture. Cancer Res., 19, 23-27.

5) Macpherson, I. \& Montagnier, L. (1964) Agar suspension culture for the selective assay of cells transformed by polyoma virus. Virology, 23, 291-294.

6) Odashima, S. (1964) Establishment of ascites hepatomas in the rat, 1951-1962. Nat. Cancer Inst. Monograph, 16, 5l-93.

7) Schleich, A. (1973) The confrontation of normal and malignant cells in vitro. In: Chemotherapy of Cancer Dissemination and Metastasis, edited by S. Garattini \& G. Franchi, Raven Press, New York, p. 51.

8) Yamane, I. \& Nakano, N. (1966) Long-term culture of the ascites form of a mouse mammary tumor in serum-free media. Tohoku J. exp. Med., 88, 203-214. 